\title{
INNOVATIVE IDEAS IN REGIONAL RESEARCH: A MESSAGE FROM PAKISTANI JOURNAL EDITORS
}

Received: Oct 30, 2019

Accepted: Oct 31, 2019

Aamir Raoof Memon ${ }^{1,2 *}$ http://orcid.org/0000-0002-3203-418X

Fatema Jawad ${ }^{\mathbf{2 , 3}}$ https://orcid.org/0000-0003-4120-5072

${ }^{1}$ Institute of Physiotherapy \& Rehabilitation Sciences, Peoples University of Medical \&

Health Sciences for Women, Nawabshah (SBA), Sindh, Pakistan

2Journal of Pakistan Medical Association, Karachi, Pakistan

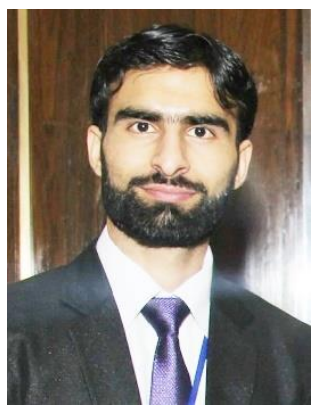

3Department of Diabetology, Sindh Institute of Urology and Transplantation, Karachi, Pakistan

\section{*Corresponding author:}

Aamir Raoof Memon, Assistant Professor, Institute of Physiotherapy \& Rehabilitation Sciences, Peoples University of Medical \& Health Sciences for Women, Nawabshah (SBA), Sindh, Pakistan;

Twitter handle: @DptAamir; E-mail: dpt.aamir@gmail.com

Keywords: Research design, Biomedical research, Writing, Periodicals as topic, Central Asia, Pakistan How to cite: Memon A. R., Jawad F. Innovative ideas in regional research: a message from Pakistani journal editors. Cent Asian J Med Hypotheses Ethics 2020;1(1):60-62. https://doi.org/10.47316/cajmhe.2020.1.1.08

Writing and publishing scholarly articles might be an uphill task for developing country authors. In Pakistan, over five dozen peer-reviewed journals are recognized by the Higher Education Commission of Pakistan and the Pakistan Medical and Dental Council. Of these, only three medical journals are currently indexed in MEDLINE. Limited financial resources, lack of training in research methodology, and inadequate English writing skills may affect some Pakistani authors and make it difficult for them to turn their innovative ideas into manuscripts publishable by indexed regional and global journals [1]. The scale of the problem is magnified due to the emergence of the so-called predatory journals that primarily prey on authors from non-mainstream science countries [2].
We strongly believe that clear and well-structured ideas and hypotheses of researchers from Pakistan and other developing countries should be nurtured and publicized by editors of indexed regional journals, such as the Journal of Pakistan Medical Association.

Innovative ideas form the basis for working hypotheses of original research and standalone scientific theories [3, 4].The ideas can be based on observations of regularities and anomalies, experience and accumulated knowledge, scientific facts, and questioned theories [5]. An idea usually leads to a general research question, which is then refined by employing specific tools, such as the 


\section{Central Asian Journal of Medical Hypotheses and Ethics| \\ 2020; Vol 1}

FINER framework (Feasible, Interesting, Novel, Ethical, and Relevant) and the PICO tool (Patient, Intervention, Comparison, and Outcomes) [5]. A comprehensive literature review is essential for formulating a research question and working hypothesis [4]. Various types of hypotheses can be divided into inductive (based on observation) and deductive (originating from theory), directional (expected direction) and non-directional (relation exists), and null (no significant relation) and alternative (significant relation) [4].

Great ideas and hypotheses may transform into research protocols and projects, promoting science regionally and globally. The novelty and testability of scientific hypotheses may pave the way for regional authors in their attempts to target influential journals.

A Scopus-based bibliometric study showed that the Journal of Pakistan Medical Association publishes mostly articles from Pakistan, Turkey, India, Iran and Saudi Arabia [5]. The annual publication activity increased greatly from 2007 onward, after the acquisition of the Journal Impact Factor (JIF).The Journal of Pakistan Medical Association is particularly attractive for regional authors due to the editorial policies and some important features. The journal editors welcome diverse article types (audit, innovation, original article, short communication, review, students' column, etc.), regularly update the author instructions, charge feasible processing and publication fees, provide immediate and free access to published items. Importantly, the so-called negative articles and surveys find their home at our journal if they meet high research standards.

The manuscript workflow is transparently presented at our journal website (https://www.jpma.org.pk/manuscript-processing).

New submissions are primarily assessed for suitability of the content, format, and language. Poorly written manuscripts with great ideas and hypotheses are offered substantive editing. Our pool of peer reviewers comprises ofregional and international experts who voluntarily donate their time to commenting on modifiable mistakes and imperfections in the submissions. Some of our reviewers help with language editing; they provide constructive and didactic comments and enable publishing articles in polished language. The peer review process is time-consuming, but the endresult is worth the effort. The ultimate responsibility for publishing innovative articles lies with the editors.

We are now planning to train regional researchers on different aspects of publishing to achieve "research literacy". Publication of related didactic articles at our journal is an integral part of the initiative. We are also upgrading our policies to publish more influential articles.

We are striving to provide more space for innovative ideas of regional authors. However, our publishing capacity has its limits. We believe that the launch of the Central Asian Journal of Medical Hypothesis and Ethics is a major step towards supporting local and regional authors, particularly those who offer great ideas, but struggle to publish in established indexed journals. It is hoped that cooperation with Pakistani editors will enhance the quality of this promising journal and expand prospects of regional cooperation.

\begin{abstract}
ARM has done Master of Philosophy in Health, Physical Education and Sports Sciences from Islamabad, Pakistan. He is currently employed at a medical university from Pakistan and is Editorial Board Member for Journal of Pakistan Medical Association and Associate Editor for BMJ Open Sport and Exercise Medicine. FJ is a Consultant Diabetologist at Sindh Institute of Urology and Transplantation, Karachi, Pakistan and Editor-inChief of the Journal of Pakistan Medical Association.
\end{abstract}

\section{FUNDING}

None

\section{AUTHOR CONTRIBUTIONS}

ARM and FJ contributed substantively to the writing of this manuscript. Both authors take full responsibility for the integrity of all parts of the manuscript.

\section{CONFLICTS OF INTEREST}

None declared

\section{DISCLAIMER}

No part of this manuscript is copied from or published elsewhere. 


\section{REFERENCES}

1. Memon AR. Research publications and education in Pakistani medical universities: Avoiding predatory journals and improving the quality of research. J Pak Med Assoc 2017;67(6):830-833.

2. Gasparyan AY, Nurmashev B, Udovik EE, Koroleva AM, Kitas GD. Predatory Publishing Is a Threat to NonMainstream Science. J Korean Med Sci 2017;32(5):713-717.

3. Bains W. How to write up a hypothesis: the good, the bad and the ugly. Med Hypotheses 2005;64(4):665668.

4. Toledo AH, Flikkema R, Toledo-Pereyra LH. Developing the Research Hypothesis. J Invest Surg 2011; 24(5):191-194.

5. Vandenbroucke JP, Pearce N. From ideas to studies: how to get ideas and sharpen them into research questions. Clin Epidemiol 2018;10:253-264.

6. Memon AR. Bibliometric analysis of the Journal of Pakistan Medical Association during the period from 1965 to 2018. J Pak Med Assoc 2019;69(8):1150-1158.

\section{Өлкетанудағы инновациялық идеялар: Пәкістандық журнал редакторларының жолдауы}

Түйін сөздер: Зерттеу дизайны, Биомедициналық зерттеулер, Жазба, Тақырып ретінде мерзімді басылымдар, Орталық Азия, Пәкістан

Дәйексөз үшін: Мемон А.Р., Джавад Ф. Өлкетанудағы инновациялық идеялар: Пәкістандық журнал редакторларының жолдауы. Медициналық гипотеза мен этиканың Орта Азиялық журналы. - 2020. - №1 (1). - Б. 60 - 62. https://doi.org/10.47316/cajmhe.2020.1.1.08

\section{Инновационные идеи в региональных исследованиях: сообщение пакистанских редакторов журналов}

Ключевые слова: Дизайн исследований, Биомедицинские исследования, Письменность, Периодика как тема, Центральная Азия, Пакистан

Для цитирования: Мемон А.Р., Джавад Ф. Инновационные идеи в региональных исследованиях: сообщение пакистанских редакторов журналов. Центральноазиатский журнал медицинских гипотез и этики. - 2020. - №1(1). - С. 60 - 62. https://doi.org/10.47316/cajmhe.2020.1.1.08 